\title{
Tobacco related bar promotions: insights from tobacco industry documents
}

\section{S K Katz, A M Lavack}

See end of article for authors' affiliations

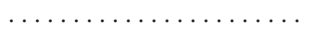

Correspondence to: Anne M Lavack, PhD Faculty of Administration, University of Regina, Regina, Saskatchewan, Canada S4S OA2: anne.lavack@uregina.ca
Objectives: To examine the tobacco industry's use of bar promotions, including their target groups, objectives, strategies, techniques, and results.

Design: Over 2000 tobacco industry documents available as a result of the Master Settlement Agreement were reviewed on the internet at several key web sites using keyword searches that included "bar", "night", "pub", "party", and "club". The majority of the documents deal with the US market, with a minor emphasis on Canadian and overseas markets.

Results: The documents indicate that bar promotions are important for creating and maintaining brand image, and are generally targeted at a young adult audience. Several measures of the success of these promotions are used, including number of individuals exposed to the promotion, number of promotional items given away, and increased sales of a particular brand during and after the promotion.

Conclusion: Bar promotions position cigarettes as being part of a glamorous lifestyle that includes attendance at nightclubs and bars, and appear to be highly successful in increasing sales of particular brands. op $\mathrm{n}$ recent years, increasing restrictions on tobacco marketing have lead tobacco companies to seek out promotional opportunities to target consumers in adult-only venues. This has resulted in bars, taverns, and pubs becoming "ground zero" for this innovative marketing strategy. ${ }^{1}$ The tobacco industry has begun to rely extensively on bars and nightclubs as a way to reach a young adult audience, with the advertising of bar promotions reaching a broader audience, both older and younger. ${ }^{2}$ Bars represent one of the few available adult only venues where the tobacco industry can advertise and promote their products freely, while avoiding potential public criticism that these marketing efforts spill over into an underage market.

In the academic literature, no papers have been published to date that specifically deal with the tobacco industry's use of bar promotions, but anecdotal evidence in the popular press indicates that bar promotions are becoming increasingly common for tobacco brands. ${ }^{3}$ At the same time, however, various jurisdictions are considering the introduction of legislation to ban smoking in bars. ${ }^{4}$ This would create further challenges and difficulties for tobacco companies that are currently using bar promotions.

To examine this phenomenon of tobacco bar promotions further, we turned to the tobacco industry's own documents to discover more about the use of bar promotions, including target groups, objectives, strategies, techniques, and results. The results of this analysis provide insight into the success of bar promotions as a marketing device for tobacco companies.

\section{METHODS}

The Master Settlement Agreement between the US states and the tobacco companies has provided a rich source of tobacco industry documents held in hard copy format at two major depositories: the Minnesota Depository (33 million pages of documents) and the Guildford Depository near London, UK (six million pages of documents). The Minnesota Depository documents are also conveniently available on the internet, and can be viewed at individual tobacco company web sites, or through a comprehensive online gateway at http:// my.tobaccodocuments.org. Documents accessible from this site include those from American Tobacco Company, Brown \& Williamson, Lorillard, Philip Morris, and RJ Reynolds, as well as the Tobacco Institute and Center for Tobacco Research. The Guildford Depository contains documents from British American Tobacco Company (BATCo), a multinational corporation with operations in over 80 countries around the world and the parent company of Brown $\&$ Williamson in the USA and Imperial Tobacco Ltd in Canada. BATCo has not made the Guildford documents available on the internet, but a small partial collection of approximately 100000 of these documents is located on two Canadian web sites (maintained by Health Canada and by the provincial government of British Columbia). ${ }^{5}$

These three web sites formed the basis for choosing a sample in this qualitative research study. ${ }^{6}$ Keyword searches on each of the three web sites included "bar", "night", "club", "pub", "tavern", "party", and "nightclub", linked with "promotion". This Boolean search resulted in a total of 2218 documents from the US documents web site, 118 documents from the Health Canada web site, and 12 documents from the British Columbia government web site, for a total of 2348 documents (see table 1 for results of the key word searches). However, scanning through these document titles revealed many spurious matches, including articles relating to bar codes, bar associations, pub-licity, and clubs of all types. Therefore, the title of each of the 2348 documents was briefly reviewed, and if it appeared unlikely to be related to the topic of bar promotions it was discarded from the sample. This procedure removed approximately 1700 documents from the sample.

For the remaining 500 documents, the "find" function was used to search for the relevant key words within the document (where available for pdf documents), or the document was visually scanned to find the relevant key words. In this manner, it was possible to determine how extensively each document dealt with bar promotions. As a result of this procedure, approximately 100 documents were located which contained either extensive descriptions of bar promotions or were entirely dedicated to bar promotions.

For each of these documents containing significant references to bar promotions, relevant excerpts were printed out to facilitate qualitative analysis. Both researchers examined the relevant excerpts in order to gain an understanding of the many facets of bar promotions and how they are used, and to determine whether these promotions were a successful 
Table 1 Keyword search results

\begin{tabular}{|c|c|c|c|c|c|c|c|}
\hline \multirow[b]{2}{*}{ Single keyword } & \multicolumn{3}{|c|}{ Number of hits } & \multirow[b]{2}{*}{ Combined keywords } & \multicolumn{3}{|c|}{ Number of hits } \\
\hline & Website 1 & Website 2 & Website 3 & & Website 1 & Website 2 & Website 3 \\
\hline bar & 5176 & 87 & 0 & bar + promotion & 428 & 25 & 12 \\
\hline night & 3449 & 31 & 1 & night + promotion & 257 & 10 & 0 \\
\hline club & 17662 & 35 & 10 & club + promotion & 1,367 & 15 & 0 \\
\hline pub & 1663 & 30 & 0 & pub + promotion & 158 & 0 & 0 \\
\hline tavern & 892 & 1 & 0 & tavern + promotion & 36 & 0 & 0 \\
\hline party & 5236 & 250 & 100 & party + promotion & 350 & 106 & 12 \\
\hline nightclub & 192 & 0 & 0 & nightclub + promotion & 36 & 0 & 0 \\
\hline promotion & 80062 & 198 & 12 & & & & \\
\hline \multicolumn{5}{|c|}{ (bar or night or club or pub or tavern or party or nightclub) and (promotion) } & 2218 & 118 & 12 \\
\hline
\end{tabular}

Website 1-US Minnesota Documents: http://my.tobaccodocuments.org/

Website 2-Health Canada Guildford Documents: http://www.ncth.ca/Guildford.nsf

Website 3-British Columbia Guildford Documents: http://www.hlth.gov.bc.ca/cgi-bin/guildford_search.cgi

marketing tool for tobacco companies. Key passages within the documents were highlighted.

An important part of this examination of documents was searching for emerging ideas and themes, which facilitated an organisation of the documents around these major themes.

\section{RESULTS}

Documents discussing bar promotions were found for a total of 12 different brands from six different companies (table 2). The major themes that emerged through this qualitative analysis were: ( 1 ) the importance of bar promotions as a tool for creating and reinforcing brand image; (2) a focus on target marketing aimed at young adults and specific ethnic groups; (3) the use of bar promotions for brand trial and sampling; (4) the use of incentives and branded promotional items to increase brand visibility; (5) the use of bar promotion contests and surveys as a means of generating names for database marketing; (6) the impact of social leaders in the bar environment on information dissemination and the psychological and social implications of a bar environment; and (7) the use of creativity and innovation in designing bar promotions; (8) extending the reach of bar promotions; and (9) measuring the effectiveness of bar promotions. Overall, the tobacco industry documents indicate that bar promotion has become a key strategy to increase consumer involvement with cigarette brands.

It should be noted that given the dominant size of the Minnesota Depository database compared to the Canadian and Guildford databases, the majority of the documents deal with US bar promotions. Therefore, unless otherwise noted as

Table 2 List of brands involved in bar promotions

\begin{tabular}{ll}
\hline Company & Brands \\
\hline American Tobacco Company & Malibu \\
British American Tobacco Co & $\begin{array}{l}\text { JPS (John Player Special) } \\
\text { Lucky Strike (International) }\end{array}$ \\
Brown \& Williamson & $\begin{array}{l}\text { Kool } \\
\text { Eli Cutter } \\
\text { Lucky Strike }\end{array}$ \\
& Newport \\
Lorillard & Virginia Slims \\
Philip Morris & Marlboro \\
& Bucks \\
RJ Reynolds & Camel \\
& Dakota \\
\hline
\end{tabular}

BATCo or international, the reader can assume that the document excerpts are referring to the US market. Each of the following sections deals with one of the major theme areas that emerged from the qualitative analysis of the documents.

\section{Creating and reinforcing brand image}

Given that many cigarette brands are relatively similar in flavour, creating a unique brand image is an important means of differentiating a particular cigarette brand in the minds of consumers. While conventional advertising is the usual method for creating brand image, increasing advertising restrictions have resulted in tobacco companies exploring other means of communicating brand image.

It appears that one of the key roles of bar promotions, therefore, is to create and reinforce brand imagery. This role is discussed in a number of documents for different brands. For example, a 1990 Brown \& Williamson document entitled "Bar/Tavern Exploratory" discusses using bar promotions "to build brand imagery":

"There are strategic uses for bar promotions. They can be developed, for example, to build brand imagery. . . . Bar promotions can be tailored to meet the needs of the brand and the desires of the audience. They can be used to develop and reinforce brand image. ${ }^{17}$

A Virginia Slims document entitled "Virginia Slims Legends Bar Night Concepts" outlines the objectives for their bar promotion as being, "Communicate and reinforce the brand's image $^{\prime \prime 8}$ A 1987 Virginia Slims document suggests that a key strategy is to, "Create a presence in the bar that is consistent with the brand image of fun, fashion and male/female friction."' ${ }^{\prime \prime}$ Bar promotions link a bar environment with a tobacco brand name, in the hope that consumers will associate the brand with the attributes of the bar environment (that is, lively, fun-loving, high-energy, youthful exuberance, trendy, fashionable, etc).

\section{Target marketing}

Bars, taverns, and lounges that serve alcoholic beverages tend to cater to a particular clientele. A 1990 Brown \& Williamson document describes how bar promotions can be used to focus on a specific target group:

"Bar promotions have the flexibility to be implemented at a local, regional or national level, or they can be developed as a series of events that address all three. Bar promotions can be tactical in nature. They can reach different audiences of similar age and shared interest. The atmosphere/theme of a given bar attracts specific age ranges and clientele of similar socioeconomic backgrounds." 10 
Many young adults enjoy drinking and socialising in a bar environment, so there are a relatively large number of bars that focus on the young adult demographic group. Since young adults are also the preferred target group for tobacco companies, it is little wonder that bar promotions have become such a popular means of promoting cigarette brands. Bars also represent a smoker friendly environment in a society where smoking restrictions in public places, work places, and restaurants are increasingly the norm. Young adults who frequent bars tend to be more likely to smoke, making bars a comfortable location in which to congregate.

Most tobacco companies include very detailed target group descriptions as part of their planning for bar promotions. BATCo's international JPS brand defines its desired outlets as being those "frequented by the Target Consumer - including Night Clubs, Discos, Restaurants and Lounges." ${ }^{11}$ The 1989 JPS Pack Test document describes the "desired user" of its JPS brand as being from "higher income groups, 18-30 years old, largely male" and "currently smoking Dunhill/Rothmans/B \& $\mathrm{H}$ or Marlboro: high status international brands". ${ }^{12}$ This document further describes the psychographic profile of the international JPS customer as being a "style conscious" consumer who enjoys bars and clubs:

\begin{abstract}
"Our consumers are style conscious, but not at the cutting edge of fashion: a follower rather than a leader. However, they like to think of themselves as up-to-date and they admire those who are more courageous and lead trends. They have a relatively high disposable income, with high purchases of clothes, entertainment (restaurants, cinema, clubs etc.), music. They are 'high-profile', active and sociable. .. . Their cigarette brand is a cheap and easy way of showing their style, their belonging to a certain group. They can 'join' the world of real fashion leaders without the more radical implications of buying distinctive clothes, etc." ${ }^{13}$
\end{abstract}

This focus on young "fashion influencers" is also evident in other companies' documents. A 1994 BATCo marketing intelligence document entitled "How Marlboro Led the Pack" summarises Marlboro's focus on the "younger smoker" through the "club/disco/bar environment" ${ }^{14}$ :

"a key factor in the success of Marlboro advertising has been its consistent targeting of 18-24 year old men who are sophisticated, intelligent city dwellers, advertising literate and most importantly, fashion influencers. PM has managed to develop and maintain the appeal of Marlboro for the younger smoker; to the extent that for this target consumer, it is more trendy and exclusive (it will make you feel rugged, macho, sexy) than mainstream cigarettes smoked by the older generation. By targeting communications at the club/disco/bar environment (eg. sampling) and using well produced direct mail magazines, covering topics that are currently in vogue with the younger generation, PM successfully builds up brand loyalty at an early stage. ${ }^{\prime 15}$

The importance of this target market for Marlboro is underlined in a Philip Morris document, wherein a bar promotion is described as targeting "our most important audience, young adult males":

"Marlboro has signed a two year agreement with the owner of America's Original Sports Bar as the exclusive tobacco sponsor and promoter in a chain of eight large sports bars owned by Harborage Inc. Marlboro will be highlighted in each club offering year round premier vis- ibility for the brand at venues frequented by our most important audience, young adult males." ${ }^{\prime 16}$

Eli Cutter, a Brown and Williamson brand, used its bar promotions to compete head-on with Philip Morris to try to attract Marlboro smokers. The 1986 document entitled "Creative Brief: Eli Cutter Bar Promotion" outlines their target consumer as being blue collar white males, age 21-35, "Marlboro and Camel smokers primarily, Winston smokers secondarily."17 The "tone and manner" of the promotion placed a clear focus on the "young adult male" target consumer:

"Tone and Manner [should be] appealing to young adult male smokers age $21+$. . Fun, but not silly or outrageous . . Treats brand with the respect due to a leader in a product category . . . Reinforces Old West theme without getting too 'cowboyish'." ${ }^{18}$

According to a 1988 document, the Merit brand from Philip Morris focused its bar promotions on both males and females in the "important 21-34 age segment":

"As you know, the important 21-34 age segment has been an increasing problem for Merit. We agreed in our August marketing planning session that testing a streamlined bar sampling program was a logical strategy to induce trial among younger smokers. ${ }^{19}$

Some bar promotions are directed at target groups relating to race and ethnicity. For example, "Kool Nights Bar Promotions" outlined the objective of Kool's bar campaign:

"The objectives of this test program are to conduct bar promotions in inner-city Black neighborhoods to increase awareness and trial of KOOL MILDS and to further reinforce KOOL as the leading menthol brand." 20

The location selection for this program consisted of "Innercity locations that are popular and attract adult, KOOL target audience smokers." ${ }^{21}$ Other prime locations for KOOL bar promotions are venues near naval and military bases:

"It seems the venues located in close proximity to the bases attract a large crowd of demographically desirable consumers. By implementing events on base we could assist in relieving boredom, boost camp morale as well as encourage brand trial and conversion in a fun, exciting atmosphere." 22

Marlboro Menthol also defined their target consumer along racial lines in "Menthol - Event Sponsorship - Marlboro Menthol Inner City Bar Nights". Marlboro Menthol's objective was to increase trial, awareness and conversion among:

"the Black smoker audience-a smoker group which represents approximately $20 \%$ of the menthol category sales and among whom Marlboro Menthol has little share." ${ }^{\prime 23}$

A 1987 Virginia Slims document suggests that a key strategy is to "Target Black urban bars with a high concentration of target smokers." ${ }^{24}$ The ability to target a particular demographic or psychographic group is one of the major reasons that bar promotions have become increasingly popular in recent years. 
Cigarette companies pay careful attention to finding appropriate outlets to host bar promotions. A Benson $\&$ Hedges international document entitled "Merchandising" described "key outlets" for marketing and promotions as being "bars, restaurants, cafés, night clubs, hotels, etc." These key outlets were identified through a detailed process known as a "block check," described as follows:

\begin{abstract}
"In order to make sure you don't miss any key outlets the best way to double check what you have received from others and find key outlets is to block check by area. This is done by using by using a map and turning left at every road until you have covered a designated area. Record each outlet you find and see if it fulfils the criteria we have used to define key outlets. Do this throughout your area until you have covered every road, lane, shopping mall, etc. . . . You should enter each outlet because you may get a totally false picture from the outside. Introducing yourself may be advisable, 'I'm ....... from Benson \& Hedges and I'm doing a survey of the area to ensure that we are giving you the best possible service we can'."25
\end{abstract}

This micro approach to finding key outlets illustrates the importance of targeting appropriate establishments for bar promotions, and the lengths to which tobacco companies go to ensure blanket coverage of a geographic area.

\section{Brand trial and sampling}

While bar promotions are intended to reinforce brand image and increase brand awareness, of key importance is their ability to facilitate brand sampling and brand trial. In a 1990 Brown \& Williamson document, bars are described as being an "excellent venue" to "generate quality trial":

"Bars are an excellent venue to promote brand awareness and generate quality trial. People who frequent these locations are generally over 21 years of age or older [sic] and are known to smoke and drink. They are sociable people and generally receptive to new things." ${ }^{26}$

A Virginia Slims document outlines the objectives for the Virginia Slims Legends Bar Night Concepts as being to, "Create trial and purchase opportunities among competitive smokers and among the Virginia Slims franchise". ${ }^{27}$ A 1987 Virginia Slims document suggests that a key strategy is to, "Provide sampling opportunities at the event". ${ }^{28}$

A 1989 American Tobacco Company memo discusses bar promotions for the MALIBU brand, focusing on the importance of generating trial:

\footnotetext{
"Attached is a proposal to test a MALIBU Bar Event Sponsorship in both Hartford, CT. and Denver, CO. The objectives of this program are as follows: . . . 3) Generate positive, pro-active trial among the younger adult smoker universe most receptive to MALIBU's basic positioning. ${ }^{29}$
}

A 1990 plan presented to RJ Reynolds for their Dakota brand discussed the specific details of their bar sampling plan:

". . . formal sampling will occur in appropriate venues. Sample will consist of two sample packs plus a Dakota lighter. Sampling will be conducted at appropriate clubs, bars and adult recreation facilities." ${ }^{\prime 30}$

A 1991 American Tobacco Company document describes the benefits of a bar promotion as allowing product sampling "in a 'smoker friendly' environment". ${ }^{31}$ It is clear that generating trial is an important part of bar promotions, and brand sampling is a key activity included in many bar promotions.

\section{Using incentives and branded promotional items to increase visibility}

Tobacco companies have sought promotional events that not only include branded advertisements and merchandise in a bar, but also allow patrons to take home branded incentives and other reminders of the promotion. The Brown \& Williamson "Bar/Tavern Exploratory" document explains that "incentives" are a key factor in planning a bar promotion:

"Incentives are key to successful bar promotions, for both the smoker and the proprietor alike .... The distribution of incentives to the smoker in this environment is a means of introducing them to the brand in a social atmosphere, with a fun surround and a receptive environment. ${ }^{\prime 32}$

Incentives often take the form of branded merchandise, such as hats or $\mathrm{T}$ shirts bearing the cigarette brand name. A 1989 KOOL memo gave some recommendations about how to "spice up" their bar promotions by using various types of branded merchandise, some of which would turn a bar patron into a "walking billboard advertisement":

"I would like to make a few suggestions which I think would spice up our bar promotions in the future...

- Manufacture and purchase an inexpensive painters cap to give out at the promotions. (Excellent walking billboard advertisement.)

- Manufacture and purchase green and white balloons with our $\mathrm{KOOL}$ logo to be placed in the club to create a party atmosphere.

-Allocate several cases of $\mathrm{KOOL}$ lighters or $\mathrm{KOOL}$ matches with caddies to be distributed to the patrons.

-Develop a drink stirrer/napkin holder to be placed at each bar station. This could be a permanent piece of advertisement after the promotion is completed." ${ }^{\prime 3}$

The use of these various types of branded merchandise serve the role of increasing visibility of the brand name, and also provide permanent keepsakes that serve as constant reminders of the brand name.

A 1994 Philip Morris document for Marlboro outlined the objectives of its "Section 51 Bar/Restaurant Visibility Test" as being a test of their ability to:

"-Generate visibility, and leading brand imagery of Marlboro in key bars, clubs, and restaurants in Section 51 - a highly developed Camel geography.

Penetrate between 400 and 500 locations in a period of 4-6 weeks (beginning on or before June 13, 1994).

- Understand which Permanent POS bundles or items are most effective and most readily accepted and placed in the various classes of bar/restaurant establishments.

- Identify potential on-premise product placement and display opportunities which will lead to incremental sales and distribution. 
- Investigate the interest in, and feasibility of a POS retention program - where retailers are rewarded quarterly for prominent, on-going display of Marlboro Permanent visibility items with useful, yet inexpensive Marlboro bar related items (bar organizers, napkins, cups, stirrers, coasters, matches etc." ${ }^{134}$

One of their strategies to support these objectives was to:

"Encourage Bars, Clubs, and Restaurants (in Sec.51) which cater to YAM's and YAF's to accept and prominently display select Marlboro image POS items. ${ }^{135}$

"YAM's" are young adult males and "YAF's" are young adult females, key target groups for the Marlboro brand. By prominently displaying Marlboro POS (point-of-sale) items, Marlboro brand visibility would be considerably enhanced.

\section{Generating names for database marketing}

Database marketing has become popular among major tobacco companies as a means of keeping in touch with smokers. These databases are used as mailing lists for sending smokers free samples, corporate magazines, and branded merchandise catalogues. Bar promotions can be useful in gathering smoker names for database marketing. Contests or surveys among bar patrons are a means of gathering smokers' names that are entered into the permanent database. For example, a Virginia Slims document outlines one of the objectives for the Virginia Slims Legends Bar Night Concepts as being to "generate names for the Virginia Slims database" ${ }^{36} \mathrm{~A}$ 1989 KOOL memo provided some recommendations about how to "develop a smoker survey card to gain smoker profile information." ${ }^{37}$ A 1989 American Tobacco Company memo discusses bar promotions for the MALIBU brand, and mentions that a key objective is to "develop a database of younger adult smokers for follow up direct marketing activities". ${ }^{38}$ These excerpts underline the importance of bar promotions in developing lists of names for database marketing.

\section{Bar environment and social influence}

One of the most important aspects of bar promotions relates to the impact of social influence on product usage behaviour and brand selection. Social influence theory suggests that individuals may conform to meet the expectations of a person or group. ${ }^{39}$ Research into reasons for smoking uptake among adolescents has shown that social influence, especially peer smoking and peer approval of smoking, are predictors of smoking behaviour. ${ }^{40}$ Although over $80 \%$ of smokers begin to smoke before the age of 18 , there is still opportunity for young adults to be influenced to begin smoking or continue smoking once they have reached the age of majority. The bar environment presents an ideal social context for tobacco companies to focus on opinion leaders in order to influence smoking status and brand choice. ${ }^{41-43}$

A review of tobacco industry documents makes it clear that tobacco companies have significant knowledge of the psychological and social issues at play in the bar environment. For example, in a 1984 BATCo international document, the purpose of "Project Whisper" was described as:

" . . .research into defining social opinion leaders, the situations in which their activities are most potent, and means of influencing these opinion influencers with appropriate product information and usage habits." ${ }^{44}$

Intended to research the social interactions within bars and to formulate ways to influence the greatest number of bar patrons, the focus of "Project Whisper" was described under a heading entitled "The Product-Consumer-Environment Interactions":

"The focus of Project Whisper has been on the role of individuals who may be regarded as models or opinion leaders within their communities. . . The role of such individuals as models is significant since they also appear to be the earliest adoptors of new ideas or habits and thus become the route through which new information enters the community. The rationale of Project Whisper is straightforward-influence an opinion leader with your product communication and you are at the same time achieving dissemination of that communication through his sociometric network. An additional aspect of this type of communication is that it traditionally takes place in locations where a high degree of opinion transfer and modelling behaviour is observed. This is seen in the British public house or night club, and has equivalent phenomena in all societies." ${ }^{45}$

By carefully defining the roles and activities of the target consumer, BATCo furthered its brand information dissemination through the "grass roots gossip networks" found in bars and nightclubs. ${ }^{46}$ Given that BATCo has operations in over 80 countries around the world, including the USA and Canada, this represents a significant worldwide effort.

A 1992 Phillip Morris document entitled "Marlboro Medium Distribution in Vending, Bars and Restaurants" suggests there is a social "need" for their product in the bar environment, and stresses the importance of product availability in bars and of being situated at the "in spots":

"First of all, for a brand like Medium, it is essential that our target audience can find it where they consume or 'need' it. If the brand is not available in social situations, our consumer does not have the option to go on to 'the next store'. Secondly, its presence/availability in above universe is image building especially when supported with appropriate materials. RJR, with Camel, is doing a far superior job to us all over the country and in particular in 'in spots'." 47

A Benson and Hedges document suggests that tobacco bar promotions reinforce the social aspects of smoking by bringing together good times, "classic smoking situations" and their brand of cigarettes. ${ }^{48}$ An excerpt from a 1995 Marlboro report points out that, "Bars are smoker friendly - sixty to seventy percent of patrons smoke." ${ }^{\prime 49}$

\section{Creativity and innovation in bar promotions}

Bar promotions have become increasingly creative and diverse in recent years. The competition for young adult smokers has forced tobacco companies to continuously introduce new and more exciting promotions. Many of these promotions are tied in with brand sponsorship, in order to build on sponsorship awareness and create excitement and synergy. For example, a Virginia Slims bar promotion idea called "First Serve" was tied in with their tennis sponsorship:

"First Serve is an element which rewards the smoker as soon as they enter the participating account. Eligible consumers receive a coupon/voucher for a discount on the first food or beverage item they are 'served'. The 'First Serve' perks could include V.I.P. status to skip the club's line or avoid paying a cover charge. ${ }^{\prime 50}$ 
Another Virginia Slims bar promotion idea called "Virginia Slims Interactive Video" provided participants with a personalised videotape:

\begin{abstract}
"Virginia Slims will place eligible consumers in retro interactive videos featuring hits from the 60's, 70's and 80 's. Participants choose from a list of songs and video backgrounds. Song lyrics are shown on a monitor so participants can sing along. Costumes and wigs are available to dress the participants for the era. Videotapes are personalized with a Virginia Slims sticker and given to the consumer to keep. Performance talent contests may be held for Virginia Slims V-Wear, department store certificates, etc. ${ }^{151}$
\end{abstract}

Virginia Slims has also considered innovative bar promotion contests, such as "Look Alike Nite":

"Women are invited to come to the bar dressed as a famous female Black celebrity-Tina Turner, Diana Ross, Janet Jackson, Whitney Houston, etc. Prizes are given out to the closest look-alikes." ${ }^{25}$

It is common for tobacco companies to engage in and report on competitive surveillance, including the creative ideas used by other tobacco companies for bar promotions. A 1982 memo entitled "Camel Lights Promotion" provides a detailed report from a Philip Morris employee regarding an RJR bar promotion for Camel Lights, including a discussion of the games, prizes, and patron reaction:

"On the scheduled night, the Camel Lights troop would arrive with one R. J. Reynolds employee (a rep or manager) and two to eight girls, depending on the size of the bar. The girls were either students or models from a local agency, according to three of the bar managers. One manager said the girls in his establishment were playboy [sic] bunnies. ... Part of the activities included plastering the bar with Camel Lights P.O.S. - posters, cards and jumbo boxes. . . Patrons of the bar were awarded gifts for doing various things. . . . The R. J. Reynolds rep would literally take over the bar. . . . Patron participation was overwhelming and enjoyed according to managers." ${ }^{53}$

These Camel Lights promotions were reported to be taking place in bars close to university campuses that attracted the young adult target consumer.

While most bar promotions include fairly conventional activities such as games, contests, and sampling, increasing competition has meant tobacco companies are seeking even more creative and attention getting activities. For example, in a 1994 document entitled "Proposal to Lorillard for Newport Special Events and Sampling Programs for Long Island", suggested events included swimwear shows, body art exhibitions, photo key chains, live bands, and sampling, thereby extending Newport Special's brand name both inside and beyond the bar environment. This document outlined various examples of patron participation events:

"After the Newport Body Art Exhibition, the artist will encourage patron participation and offer complementary Newport inspired body art to onlooking patrons of the venue. . . . At each event our trained photographer will encourage over 400 patrons to pose for a photo. The patrons will be afforded the opportunity to capture the night's excitement and leave with a developed photo, which will be inserted in our Newport imprinted photo key chain." 54
These types of promotions allow the patrons to be surrounded by a cigarette brand name while at the bar, and also allow them to take a promotional item home with them.

Theme nights are another type of bar promotion that not only includes contests, sampling, or games, but also builds an entire night around a theme associated with a particular cigarette brand. A Philip Morris document entitled "Bucks Interactive Marketing Plan" offers several theme options to incorporate the Bucks cigarette brand into a night of bar activities. Examples include "Bucks 'Boogie' Night" (in a dance club), "Bucks Night Out", and "Bucks Only Night" (for men)..$^{55}$

Philip Morris has also used bar promotions as a means of extending the reach of its Marlboro racing promotions. The use of "attractive individuals" is recommended to ensure the success of these bar promotions aimed at YAMS (young adult males):

"Given that the people who work these Marlboro Racing Bar Nights are in close contact with YAMS, we should ensure that attractive individuals are selected to work this program. Perhaps a local modelling agency could be useful when recruiting for this program. ${ }^{115}$

Another recommended strategy includes ways to maintain a permanent presence in bars, for example, creating "a Marlboro Racing corner/room by using racing photos and paraphernalia to decorate the wall(s)" and offering "a Marlboro Winners Circle drink". ${ }^{57}$

Tobacco brand themes can be extended even further with proprietary concept bars. An international document entitled "Lucky Strike Originals - Expansion into BATCo's Market" describes the proposal of a Lucky Strike concept bar and restaurant incorporating Lucky Strike signage and merchandise throughout the entire establishment:

"BAT Co. sees the function of café, bar, music club and shop as a 'total' package of success. The emphasis is on quality and American originals i.e. food, atmosphere, service and goods. These aspects are seen as paramount in correctly presenting the positioning and in supporting the brand. ${ }^{58}$

A key marketing objective inherent in the use of concept bars is outlined as follows:

" . . . to provide a communication vehicle for the Lucky Strike brand in the future. The vehicle must be consistent with the brand image, and to build global awareness for LSF as a genuine American original." ${ }^{59}$

\section{Extending the reach of bar promotions}

Tobacco companies have also used their bar related promotional efforts to extend their reach beyond the bar environment. For example, Brown \& Williamson launched its "Lucky Strike Band to Band" campaign in 2000, which involved sponsoring local band competitions at nightclubs. ${ }^{60}$ Nightclub patrons were invited to cast their vote in order to choose the winners of the band competitions, and received free merchandise for participating. Lucky Strike also used this opportunity to run ads in national music magazines, to congratulate the winning bands. In this way, a tobacco company's sponsorship of a local band contest in a nightclub environment was extended into a national magazine campaign.

Camel has followed a similar tactic, in running the "Camel Page" in New York newspapers to promote selected bars and musical events under the Camel brand name. ${ }^{61}$ Ads for the Camel Casbah Clubs represent another similar effort (fig 1). This type of advertising creates a close link between the Camel brand name and entertainment aimed at the young adult 


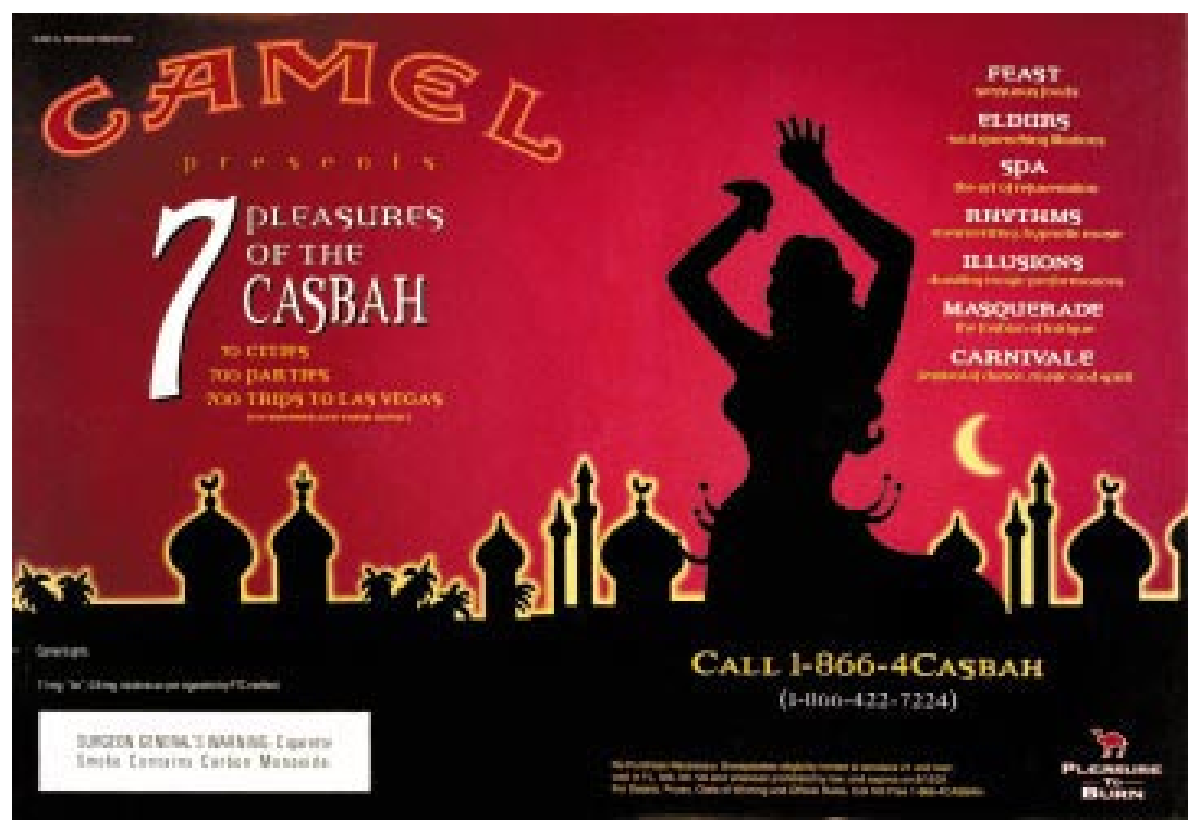

Figure 1 Ad for the Camel Casbah Clubs. This type of advertising creates a close link between the Camel brand name and entertainment aimed at the young adult market

market. Furthermore, it strengthens relationships between bars and the tobacco industry, as bars are rewarded with this free advertising in exchange for their cooperation in bar promotions. Similar advertising for major brands has become a regular feature in the weekly entertainment newspapers in many cities.

\section{Measuring the effectiveness of bar promotions}

Bar promotions are relatively expensive to produce and run effectively, compared to the use of traditional mass media. A discussion of the costs and benefits of bar promotions is presented in Brown \& Williamson's 1990 document entitled "Bar/Tavern Exploratory":

"It is important to point out that the cost per customer reached at a bar promotion would be greater than the cost associated with a retail promotion. However, the quality of the brand image created with bar nights would be greater than at retail." ${ }^{162}$

It is this greater "quality of the brand image" that makes bar promotions an effective method of creating brand awareness and trial for tobacco companies. ${ }^{63}$ Although more costly than a retail promotion, the cost of a bar promotion can compare favourably with expenses incurred in a direct mail programme:

"A national bar sampling program can be as cost efficient at generating trial as a direct mail program. The cost of a bar sampling test program is higher due to the initial set-up costs that aren't amortized over a larger number of bars."

The success of bar promotions is discussed in several documents. A Marlboro document entitled "Marlboro Resort Program" states that sales in vending machines "more than tripled":

"By promoting through the popular bars in the resort area, we can see the result of buying impulse through peer influence and promotional activity. While the results are not in yet, we have an indication that our product movement through the vending machines more than tripled in the bars we promoted in." 65

The following 1995 excerpt indicates that Marlboro can quantify the success of one of their Miami bar promotions in terms of the resulting sales of an additional 635 packs:

". . . the total man hours needed to conduct the promotion in the three locations was twelve hours. During this time we were able to sell an additional SIX HUNDRED THIRTY FIVE PACKS OF MARLBORO and generate seventy-seven survey cards using left over 1994 Marlboro Gear Items. . . Considering the number of qualifying Bars through out the United States we have the opportunity to sell an additional Nine Million Cartons while building rapport with this new smoker friendly trade class."

A 1992 KOOL document entitled "Virginia Test Market Final Report 'Kool Bar Promotion'" indicated that the bar promotion created "high levels of trial" for the brand:

"Overall, reactions in the venues regarding the brand and the events was positive. Feedback from the B\&W field personnel and our employees indicate high levels of trial in a nonhostile and festive lifestyle atmosphere. The premiums and free snapshots with the Penguin were appreciated by the patrons as were the samples and coupons. Venue management appreciated the added attraction of the events for their customers as well as the leave behind items, they were especially impressed with the neon marker boards and the personalized banners." ${ }^{67}$

Another 1992 KOOL document outlined the success of a Cleveland bar night and noted a high level of product sales:

"Consumer response to premium giveaways (can coolers, mini lighters, coupons - for those over 21 - and free 'Party KOOL' T-shirt with purchase of new KOOL) was favorable. Estimate that roughly 75 consumers purchased product within the 1.5 hours I observed the event. ${ }^{1168}$ 
Overall, it appears that bar promotions can be highly successful in increasing product sales.

\section{DISCUSSION}

This paper reviewed tobacco industry documents to gain a first hand look at the use of bar promotions. It is evident that tobacco companies consider bar promotions to be extremely worthwhile vehicles for enhancing brand image. At the same time, bars provide the opportunity to present smoking as part of a glamorous lifestyle.

It is clear that bar promotions are highly effective at increasing sales. While most of this increase in sales within the bar would result from brand switching, it is also possible that some of the increase may be attributed to smoking uptake or relapsed quitting, especially given the reduction in inhibitions that can result from alcohol consumption in bars. ${ }^{69}$ It is possible that non-smokers may become occasional smokers and associate this behaviour with bar attendance. However, tobacco industry documents reviewed in this study speak only of the potential to generate trial from competitive brand adult smokers, and do not mention whether there are any attempts to gain new smokers by using bar promotions to encourage smoking uptake.

Because inhibitions are reduced during alcohol consumption, individuals may become involved in behaviours that they do not normally engage in. A number of young adults are occasional smokers who tend to engage in this behaviour in social settings such as bars. However, during final exams or other stressful periods, this occasional smoking behaviour may become more frequent, and may even transfer to situations outside of the bar environment. Given the addictive nature of tobacco, it is possible that an occasional smoker could turn into a daily smoker during a stressful period, and then find it very difficult to return to being only an occasional smoker. Whether or not a bar promotion could potentially encourage smoking trial and uptake is not at all clear. Therefore, the role of bar promotions as a potential initiator of smoking behaviour deserves further examination.

An interesting question also arises regarding the impact of tobacco branded promotional items in bar promotions. Studies have shown that adolescents who own tobacco promotional items, or are willing to use tobacco promotional items, are more likely to smoke. ${ }^{70}{ }^{71}$ It is not clear whether this pattern extends to young adults; however, it seems possible that young adult non-smokers exposed to tobacco bar promotions and their associated promotional items may become more likely to smoke.

A further area of interest identified in the tobacco documents is the unique opportunity that a full concept bar can provide for taking advantage of legislative loopholes. ${ }^{72}$ The full concept bar entails including the tobacco brand name as an integral part of the bar name, and the entire bar is built around the brand image of the cigarette brand. This type of concept bar may become popular in the future, as tobacco companies seek ways to become more competitive in attracting and retaining their young adult target consumers.

A potential limitation of this study of tobacco documents is its reliance on key word searches and the availability of online documents. There may be other documents regarding bar promotions that were not unearthed in the process of this study. However, the topic areas covered within this article seem to be representative of bar promotions in general.

\section{Conclusion}

Overall, the tobacco industry's own documents indicate that bar promotions are an important means of creating involvement with their target consumer in a smoker friendly bar environment. These documents show a strong emphasis on target marketing and recognition of the psychological and social implications of the bar environment. Furthermore, the

\section{What this paper adds}

Bar promotions represent a unique marketing opportunity for tobacco companies to target individuals in adult only venues. However, to date no academic papers have been published regarding the tobacco industry's use of bar promotions. Articles in the popular press, as well as advertising in weekly entertainment newspapers in many metropolitan areas, indicate that bar promotions are becoming more popular for tobacco brands. Increasingly, however, many jurisdictions are considering banning smoking in bars.

This research scanned over 2000 tobacco industry documents available on the internet as a result of the Master Settlement Agreement, and reviewed over 100 of these in depth. According to these documents, bar promotions tend to be targeted at a young adult audience, and these promotional events are carefully planned and executed. Bar promotions position cigarettes as being part of a glamorous lifestyle that includes attendance at nightclubs and bars. These promotions also appear to be highly successful in increasing sales of particular brands. While most of this increase in sales would result from brand switching, it is also possible that some of the increase may be attributed to smoking uptake and/or relapsed quitting, especially given the reduction in inhibitions that can result from alcohol consumption in bars. However, tobacco industry documents related to bar promotions discuss only competitive brand switching among adult smokers.

importance of the bar promotion for promoting and reinforcing brand image is underlined.

In recent years there has been a push by many state/ provincial and municipal governments to legislate smoke-free bars and restaurants. ${ }^{73}$ The effectiveness of bar promotions may well explain why the tobacco industry waged such a hard fought battle against non-smoking bars in California. ${ }^{74}$ The tobacco industry will continue to vigorously react through lobbying and other efforts, in order to protect this ideal venue for innovative marketing tactics.

\section{ACKNOWLEDGMENTS}

The authors are grateful for the financial assistance of the Social Sciences and Humanities Research Council of Canada (SSHRC), the University of Winnipeg, and the Canadian HRDC Summer Career Placement programme. Thanks also to the anonymous reviewers who provided excellent feedback on this paper.

Authors' affiliations

S K Katz, University of Alberta, Edmonton, Alberta, Canada A M Lavack, University of Regina, Regina, Saskatchewan, Canada

\section{REFERENCES}

1 Jarvis S. They're not quitting. Marketing News 2000;34(24).

2 Graham C. Tobacco companies heat up the nightclub scene. St Petersburg Times August 11, 1995

3 Spethmann B. When the smoke clears. Promo July 1998

4 Western Report. Want a smoke? Step outside . . the country. Western Report 1996;1 1 (27): 13

5 Sibbald B. Will litigation become part of public health arsenal in Canada's war against smoking. Can Med Assoc J 2000;162;1608-9.

6 Website 1: http://my.tobaccodocuments.org/ U.S. Minnesota Documents. Website 2: http://www.ncth.ca/Guildford.nsf Health Canada Guildford Documents. Website 3: http://www.hlth.gov.bc.ca/ cgi-bin/guildford_search.cgi B.C. Guildford Documents

7 Lyle K. Bar/Tavern Exploratory. Brown and Williamson. September 7,1990. Access Date: November 1, 2001. Bates No. 670918954-8958. URL: http://my.tobaccodocuments.org/ view.cfm?docid $=1$ 1840884\&source=snapBW\&Showlmages=ye $s$. Quoted on p. $670918954-5$

8 Reynolds GM. Virginia Slims Legends Bar Night Promotions. Philip Morris. April 14, 1994. Access date: November 1, 2001. Bates No. 2040563299-3312. URL: http://my.tobaccodocuments.org/ 
view $\mathrm{cfm}^{2}$ docid $=11840884$ \& source $=$ snapBW \& Showlmages $=y e \mathrm{~s}$. Quoted on p. 2040563299.

9 Robinson WA. Virginia Slims Ethnic Bar Nite Recommendations. Philip Morris. February 3, 1987. Access date: November 1, 2001. Bates No. 2045083270-3286. URL: http://my.tobaccodocuments.org/ view $\mathrm{cfm}$ ?docid $=2045083270 / 3287 \&$ source=SNAPPM\&Showl mages=yes. Quoted on p. 2045083271

10 Lyle K. Bar/Tavern Exploratory. Brown and Williamson. September 7,1990. Access Date: November 1, 2001. Bates No. 670918954-8958. URL: http://my.tobaccodocuments.org/ view. $c f m$ ?docid $=11840884 \&$ source=snapBW\&Showlmages=ye $\mathrm{s}$. Quoted on p. 670918954

11 Alternative \# 1 - JPS as a Niche, Prestige Brand. British American Tobacco Company. August 31, 1993. Access date: November 1, 2001 Bates No. 300292771-2775. URL: http://www.ncth.ca/Guildford.nsf/ 97ed27ef6fc5e7fa852569ca006ff2c8/

31 bb64367a4c90e9852569cf0066996a/\$FILE/500292771.pdf. Quoted on p. 500292772

12 George-Perutz A. JPS Pack Test. British American Tobacco Company January 25, 1989. Access date: November 1, 2001. Bates No. 302002626-2635. URL: http://www.ncth.ca/Guildford.nsf/ 97ed27ef6fc5e7fa852569ca006ff2c8/d677bdd300b57bf085256 9cf00668ea4/\$FILE/00900240.pdf. Quoted on p. 302002634.

13 George-Perutz, A. JPS Pack Test. British American Tobacco Company. January 25, 1989. Access date: November 1, 2001. Bates No. 302002626-2635. URL: http://www.ncth.ca/Guildford.nsf/ 97ed27ef6fc5e7fa852569ca006ff2c8/d677bdd300b57bf085256 9cf00668ea4/\$FILE/00900240.pdf. Quoted on p. 302002634

14 Bingham P, Holroyd K. How Marlboro Led the Pack. British American Tobacco Company. March 1994. Access date: November 1, 2001 Bates No. 500051527-1547. URL: http://www.ncth.ca/Guildford.nsf/ 97ed27ef6fc5e7fa852569ca006ff2c8/d189cd7430918a1785256 9cf00668f67/\$FILE/00200050.pdf. Quoted on p. 500051537.

15 Bingham P, Holroyd, K. How Marlboro Led the Pack. British American Tobacco Company. March 1994. Access date: November 1, 2001 Bates No. 500051527-1547. URL: http://www.ncth.ca/Guildford.nsf/ 97ed27ef6fc5e7fa852569ca006ff2c8/d189cd7430918a1785256 9cf00668f67/\$FILE/00200050.pdf. Quoted on p. 500051537.

16 Marlboro Sports Bars 1992-1993 Marketing Plan. Philip Morris. 1992. Access date: November 1, 2001. Bates No. 2041996634-6644. URL: http://my.tobaccodocuments.org/view.cfm?docid=2041996634/ 6644\&source=SNAPPM\&Showl mages=yes. Quoted on $\mathrm{p}$ 2041996634.

17 Miller R. Creative Brief. Eli Cutter Bar Promotion. Brown and Williamson. 1986. Access date: November 1, 2001. Bates No. 675129058-9060. URL: http://my.tobaccodocuments.org/ view.cfm?docid $=1160549 \&$ source $=$ snapBW\&Showlmages=yes. Quoted on p. 675129059

18 Miller R. Creative Brief. Eli Cutter Bar Promotion. Brown and Williamson. 1986. Access date: November 1, 2001. Bates No. 675129058-9060. URL: http://my.tobaccodocuments.org/ view.. fm? docid $=1160549 \&$ source=snapBW\&Showlmages=yes. Quoted on p. 675129059

19 Schewe, R. Memphis Bar Sampling. Philip Morris. September 15, 1988. Access date: November 1, 2001. Bates No. 2044387562-7563. URL: http://my.tobaccodocuments.org/view.cfm?docid=2044387562/ $7563 \&$ source $=S N A P P M \&$ Showl mages=yes. Quoted on $p$ 2044387562

20 Stowe, R. KOOL Nights Bar Promotion. Brown and Williamson. July 2 , 1987. Access date: November 1, 2001. Bates No. 671712346-2355. URL: http://my.tobaccodocuments.org/ view. $c f m$ ?docid= $1151918 \&$ source=snapBW\&Showlmages=yes. Quoted on p. 671712347

21 Stowe R. KOOL Nights Bar Promotion. Brown and Williamson. July 2 1987. Access date: November 1, 2001. Bates No. 671712346-2355. URL: http://my.tobaccodocuments.org/ view. $f f$ ? docid $=1151918 \&$ source=snapBW\&Showlmages $=y e s$. Quoted on p. 671712347

22 National Field Report. Virginia Test Market Final Report - 'Kool Bar Promotion'. Brown and Williamson. March 25, 1992. Access date: November 1, 2001. Bates No. 300124081-4089. URL: http://www.bw.aalatg.com/public.asp. Quoted on p. 300119938

23 Bible J. Menthol - Event Sponsorship Marlboro Menthol Inner City Ba Nights. Philip Morris. October 30, 1995. Access date: November 1, 2001. Bates No. 2048768695-8697. URL: http://www.pmdocs.com/ getimg asp? pgno $=0 \&$ start $=0 \& \mathrm{if}=$ avpid $x \&$ bool $=2048768695 \&$ docid $=20$ 48768695 \&docnum $=1$ \& summary $=0$ \&sel $1=$. Quoted on $p$ 2048768695

24 Robinson WA. Virginia Slims Ethnic Bar Nite Recommendations. Philip Morris. February 3, 1987. Access date: November 1, 2001. Bates No. 2045083270-3286. URL: http://my.tobaccodocuments.org/ view.cfm?docid=2045083270/3287\&source=SNAPPM\&Showl mages=yes. Quoted on p. 2045083271

25 Merchandising (Benson \& Hedges). Philip Morris. Access date: November 1, 2001. Bates No. 301656387-6409. URL: http://my.tobaccodocuments.org/ view. $\mathrm{cfm}$ ? docid $=109 \&$ source $=$ HC\&Showlmages $=y e s$. Quoted on $p$ 301656390

26 Lyle K. Bar/Tavern Exploratory. Brown and Williamson. September 7,1990. Access date: November 1, 2001. Bates No. 670918954-8958. URL: http://my.tobaccodocuments.org/ view. $c f m$ ? docid $=11840884 \&$ source $=$ snapBW\&Showlmages $=y e s$. Quoted on p. 670918954.
27 Reynolds GM. Virginia Slims Legends Bar Night Promotions. Philip Morris. April 14, 1994. Access date: November 1, 2001. Bates No. 2040563299-33 12. URL: http://my.tobaccodocuments.org/ view. $\mathrm{cfm}$ ? docid $=11840884 \&$ source $=$ snapBW \&Showlmages $=y e s$ Quoted on p. 2040563299.

28 Robinson WA. Virginia Slims Ethnic Bar Nite Recommendations. Philip Morris. February 3, 1987. Access date: November 1, 2001. Bates No. 2045083270-3286. URL: http://my.tobaccodocuments.org/ view.cfm?docid $=2045083270 / 3287 \&$ source=SNAPPM\&Showl mages=yes. Quoted on p. 2045083271

29 Brown CJ. Approval Recommendation: Request to Test a Malibu Bar Event. American Tobacco Company. 1989. Access date: November 1, 2001. Bates No. ATX030301500-1511. URL: http:// www.bw.aalatg.com/public.asp. Quoted on ATX030301500.

30 Promotional Marketing Inc. Dakota Houston Test Market 1990 Tactical Plan. R.J. Reynolds. February 27, 1990. Access date: November 1, 2001. Bates No. 507356927-6961. URL: http:// my.tobaccodocuments.org/view.cfm?docid=507356927 $-6961 \&$ source=SNAPRJR\&Showlmages=yes. Quoted on p. 507356935

31 Brown CJ. Approval Recommendation: BULL DURHAM Bar Sampling Test. American Tobacco Company. December 16, 1991. Access date: November 1, 2001. Bates No. ATX040204083-4086. URL: http://www.bw.aalatg.com/public.asp. Quoted on p. ATX040204083.

32 Lyle K. Bar/Tavern Exploratory. Brown and Williamson. September 7,1990. Access date: November 1, 2001. Bates No. 670918954-8958. URL: http://my.tobaccodocuments.org/ view.. fm? docid $=11840884 \&$ source $=$ snapBW\&Showlmages $=y e \mathrm{~s}$ Quoted on p. 670918956.

33 Paulley B. Potential Kool Bar Kit Items. Brown and Williason. February 7, 1989. Access date: November 1, 2001. Bates No. $661107012-7013$. URL: http://my.tobaccodocuments.org/ view..$f m$ ? docid $=11861728 \&$ source $=$ snapBW\&Showlmages $=y e \mathrm{~s}$ Quoted on p. 061107013.

34 Smith W. Section 51 Bar/Restaurant Visibility Test - Elements / Highlights to-date. Philip Morris. June 7, 1994. Access date: November 1, 2001. Bates No. 2041021515-1516. URL: http:// my.tobaccodocuments.org/view.cfm?docid=2041021515/ $1516 \&$ source=SNAPPM\&Showlmages=yes. Quoted on $\mathrm{p}$ 2041021515.

35 Smith W. Section 51 Bar/Restaurant Visibility Test - Elements / Highlights to-date. Philip Morris. June 7, 1994. Access date: November 1, 2001. Bates No. 2041021515-1516. URL: http:// my.tobaccodocuments.org/view. cfm?docid=2041021515/ $1516 \&$ source=SNAPPM\&Showl mages=yes. Quoted on $\mathrm{p}$. 2041021515.

36 Reynolds GM. Virginia Slims Legends Bar Night Promotions. Philip Morris. April 14, 1994. Access date: November 1, 2001. Bates No. 2040563299-33 12. URL: http://my.tobaccodocuments.org/ view..$f m$ ? docid $=11840884 \&$ source $=$ snapBW\&Showlmages $=y e s$ Quoted on p. 2040563300.

37 Paulley B. Potential Kool Bar Kit Items. Brown and Williason. February 7, 1989. Access date: November 1, 2001. Bates No. $661107012-7013$. URL: http://my.tobaccodocuments.org/ view. $\mathrm{cfm}$ ? docid $=11861728 \&$ source=snapBW\&Showlmages $=y e \mathrm{~s}$ Quoted on p. 061107013

38 Brown CJ. Approval Recommendation: Request to Test a Malibu Bar Event," 1989. Access date: November 1, 2001. Bates No. ATX030301500-1511. URL: http://www.bw.aalatg.com/public.asp. Quoted on ATX030301500.

39 Burnkrant RE, Cousineau A. Informational and normative social influence in buyer behaviour. Journal of Consumer Research 1975;2:206-15.

40 Stacy AW, Sussman S, Dent CW, Burton D. Moderators of peer social influence in adolescent smoking. Personality and Social Psychology Bulletin 1992;18; 163-72.

41 Chan KK, Misra S. Characteristics of the opinion leader: A new dimension. Journal of Advertising 1990;19:53-60.

42 Arie OG, Durand RM, Bearden WO. Attitudinal and normative dimensions of opinion leaders and nonleaders. J Psychol 1979;101:305-12.

43 Baumgarten SA. The innovative communicator in the diffusion process. Journal of Marketing Research 1975;12:12-18.

44 Product Communication Research 'Project Whisper'. British American Tobacco Company. October 22, 1999. Access date: November 1, 2001. Bates No. 403634081-4126. URL: http://my.tobaccodocuments.org/ view. $\mathrm{cfm}$ ? docid $=493 \&$ source $=$ HC\&Showlmages $=y e s$. Quoted on $\mathrm{p}$. 403634123

45 Product Communication Research 'Project Whisper'. British American Tobacco Company. October 22, 1999. Access date: November 1, 2001. Bates No. 403634081-4126. URL: http://my.tobaccodocuments.org/ view. $\mathrm{cfm}$ ? docid $=493 \&$ source=HC\&Showlmages=yes. Quoted on $p$ 403634122-4123.

46 Product Communication Research 'Project Whisper'. British American Tobacco Company. October 22, 1999. Access date: November 1, 2001. Bates No. 403634081-4126. URL: http://my.tobaccodocuments.org/ view. $\mathrm{cfm}$ ? docid $=493 \&$ source $=$ HC\&Showlmages=yes. Quoted on $p$. 403634122

47 Dangoor D. Marlboro Medium Distribution in Vending Bars and Restaurants. Philip Morris. March 2, 1992. Access date: November 1 , 
2001. Bates No. 2047536712. URL: http://my.tobaccodocuments.org/ view.. fm?docid=2047536712\&source=SNAPPM\&Showlmages =yes

48 Market Behavior Ltd. Strategic Development of Benson \& Hedges Pack Advertising in Nigeria and UAE. British American Tobacco Company. October 14, 1992. Access date: November 1, 2001. Bates No. 500155388-5450. URL: http://my.tobaccodocuments.org/ view. $\mathrm{cfm}$ ?docid $=205 \&$ source $=\mathrm{HC} \&$ Showlmages $=$ yes. Quoted on $\mathrm{p}$. 500155400

49 Mealey R. Miami Market Vision of Success Bar and Restaurant Promotions. Philip Morris. June 8, 1995. Access date: November 1 , 2001. Bates No. 2052425108-5109. URL: http:// my.tobaccodocuments.org/view. . fm?docid $=2062425108 /$ $5109 \&$ source=SNAPPM\&Showl mages=yes. Quoted on $\mathrm{p}$. 2052425108

50 Reynolds G. Virginia Slims Legends Bar Night Promotions. Philip Morris April 14, 1994. Access date: November 1, 2001. Bates No. 2040563299-3312. URL: http://my.tobaccodocuments.org/ view. $c f m$ ? docid $=11840884 \&$ source $=$ snapBW\&Showlmages $=y e s$. Quoted on p. 2040568305

51 Reynolds G. Virginia Slims Legends Bar Night Promotions. Philip Morris. April 14, 1994. Access date: November 1, 2001. Bates No. 2040563299-3312. URL: http://my.tobaccodocuments.org/ view. cfm?docid $=11840884 \&$ source $=$ snapBW\&Showlmages $=y e s$. Quoted on p. 2040568308.

52 Robinson W. Virginia Slims Ethnic Bar Nite Recommendations. Philip Morris. February 3, 1987. Access date: November 1, 2001. Bates No. 2045083270-3286. URL: http://my.tobaccodocuments.org/ view. .cfm?docid=2045083270/3287\&source=SNAPPM\&Showl mages=yes. Quoted on p. 2045083275 .

53 Steel J. Camel Lights Promotion. Philip Morris. January 19, 1982 Access date: November 1, 2001. Bates No. 2045226284-6285. URL: http://my.tobaccodocuments.org/view.cfm?docid=2045226284/ $6285 \&$ source $=$ SNAPPM\&Showl mages $=y e s$. Quoted on $p$ 2045226284-6285.

54 Apres Events Inc. Proposal to Lorillard for Newport Special Events and Sampling Program for Long Island. Lorillard. May 7, 1994. Access date: November 1, 2001. Bates No. 91999403-9406. URL: http://my.tobaccodocuments.org/view.cfm?docid=91999403/ 9406\&source=SNAPLOR\&Showlm ages=yes. Quoted on p. 91999405

55 Burnett, L. Bucks Interactive Marketing Program. Philip Morris. December 7, 1989. Access date: November 1, 2001. Bates No. 2040405571-5582. URL: http://my.tobaccodocuments.org/ view.cfm?docid=2040405571/5582\&source=SNAPPM\&Showl mages=yes. Quoted on p. 2040405577.

56 Stone M. Marlboro racing bar night program. Philip Morris. October 11, 1993. Access date: November 1, 2001. Bates No. 2042050101-0102. URL: http://my.tobaccodocuments.org/ view. cfm?docid=2042050101/0102\&source=SNAPPM\&Showl mages $=$ yes. Quoted on p. 2042050102

57 Vonmoltke N. Sports Bar Programs. Philip Morris. September 5, 1991. Access date: November 1, 2001. Bates No. 2041005297-5298. URL: http://my.tobaccodocuments.org/view.cfm?docid=2041005297/ $5298 \&$ source=SNAPPM\&Showl mages=yes. Quoted on $p$. 2041005298

58 Crossing $\mathbf{P}$, Lee J. Lucky Strike Originals - Expansion into BATCo's Markets. British American Tobacco Company. April, 1994. Access date: November 1, 2001. Bates No. $503117514-7536$. URL: http://my.tobaccodocuments.org/ view. $\mathrm{cfm}$ ?docid $=578 \&$ source $=$ HC\&Showlmages $=y e s$. Quoted on $\mathrm{p}$ 503117517

59 Crossing P, Lee J. Lucky Strike Originals - Expansion into BATCo's Market. British American Tobacco Company. April, 1994. Access date: November 1, 2001. Bates No. $503117514-7536$. URL: http://my.tobaccodocuments.org/ view.. fm?docid $=578 \&$ source $=$ HC\&Showlmages $=y e s$. Quoted on $p$. 503117527

60 Beardi C. Lucky Strike takes an original ad turn. Advertising Age May 2000.

61 Camel Page. RJ Reynolds. 1997. Access date: November 1, 2001 Bates No. 517504334 . URL: http://my.tobaccodocuments.org/ view.cfm?docid $=517504334$ $-4352 \&$ source=SNAPRJR\&Showlmages=yes

62 Lyle K. Bar/Tavern Exploratory. Brown and Williamson. September 7,1990. Access date: November 1, 2001. Bates No. 670918954-8958. URL: http://my.tobaccodocuments.org/ view. $\mathrm{cfm}$ ?docid $=11840884 \&$ source $=$ snapBW\&Showlmages=ye $\mathrm{s}$. Quoted on p. 670918957

63 Lyle K. Bar/Tavern Exploratory. Brown and Williamson. September 7,1990. Access date: November 1, 2001. Bates No. 670918954-8958. URL: http://my.tobaccodocuments.org/ view. $c f m$ ? docid $=11840884 \&$ source=snapBW\&Showlmages $=y e \mathrm{~s}$. Quoted on p. 670918957

64 Brown C. Approval Recommendation: BULL DURHAM Bar Sampling Test. American Tobacco Company. December 16, 1991. Access date: November 1, 2001. Bates No. ATX040204083-4086. URL: http://www.bw.aalatg.com/public.asp. Quoted on p. ATX040204083.

65 Ropes D. Marlboro Resort Program 1977. Philip Morris. March 3. 1977. Access date: November 1, 2001. Bates No. 2045015677-5679 URL: http://my.tobaccodocuments.org/view.cfm?docid=2045015677/ $5680 \&$ source $=$ SNAPPM\&Showl mages=yes. Quoted on $\mathrm{p}$. 2045015678.

66 Mealey R. Miami Market Vision of Success Bar and Restaurant Promotions. Philip Morris. June 8, 1995. Access date: November 1, 2001. Bates No. 2052425108-5109. URL: http:// my.tobaccodocuments.org/view.cfm?docid $=2062425108 /$ $5109 \&$ source $=$ SNAPPM\&Showl mages=yes. Quoted on $\mathrm{p}$. 2052425108.

67 National Field Report. Virginia Test Market Final Report - 'Kool Bar Promotion'. Brown and Williamson. March 25,1992. Access date: November 1, 2001. Bates No. $300119932-9971$. URL: http://my.tobaccodocuments.org/ view. $\mathrm{cfm}$ ?docid $=12183767$ \&source=snapBW\&Showlmages=ye $\mathrm{s}$. Quoted on p. 300119937.

68 Rogers, S. KOOL Revitalization Mini-Events/Bar Nights. Brown and Williamson. June 16, 1992. Access date: November 1, 2001. Bates No. 300124087-4089. URL: http://my.tobaccodocuments.org/ view.cfm?docid=11973030\&source=snapBW\&Showlmages=ye s. Quoted on p. 300124087.

69 MacDonald TK, Zanna MP, Fong GT. Decision Making in Altered States: Effects of Alcohol on Attitudes Toward Drinking and Driving Journal of Personality and Social Psychology 1995;68:973-85.

70 Unger JB, Chen, $X$. The role of social networks and media receptivity in predicting age of smoking initiation: A proportional hazards model of risk and protective factors. Addictive Behaviors 1999;24:371-81.

71 Schooler C, Feighery E, Flora JA. Seventh graders' self-reported exposure to cigarette marketing and its relationship to their smoking behavior. Am J Public Health 1996;86:1216-21.

72 Crossing P, Lee J. Lucky Strike Originals - Expansion into BATCo's Markets. British American Tobacco Company. April, 1994. Access date: November 1, 2001. Bates No. $503117514-7536$. URL: http://my.tobaccodocuments.org/ view. $\mathrm{cfm}$ ? docid $=578 \&$ source $=\mathrm{HC} \&$ Showlmages $=$ yes

73 Western Report. Want a Smoke? Step Outside . . . The Country. Western Report 1996;11(27):13.

74 Dunham J, Marlow M. Smoking bans and their differential effects on restaurants, bars and taverns. Contemporary Economic Policy $2000 ; 18: 326-33$ 